NERS JOURNAL

\section{AWAL BROS}

http://ojs.stikesawalbrosbatam.ac.id/index.php/Ners Journal

e-ISSN: 2721-6659

Kata kunci: Asi Eksklusif, Ibu Bayi, Dan Bayi 0-24 Bulan

Korespondensi Penulis:

darmin_dina@yahoo.co.id

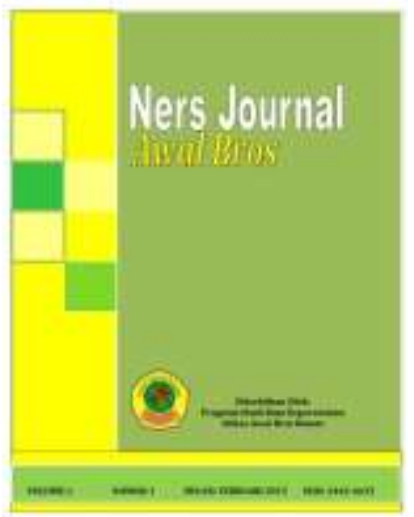

PENERBIT

Program Studi Ilmu Keperawatan STIKes Awal Bros Batam

Alamat: Jl. Abulyatama Kelurahan Belian Kecamatan Batam Kota, Kota Batam
STUDI FENOMOLOGI PEMBERIAN ASI

EKSKLUSIF DAERAH PESISIR WILAYAH

KERJA PUSKESMAS CAMPALAGIAN

KECAMATAN CAMPALAGIAN KABUPATEN POLEWALI MANDAR.

\author{
Darmin Diana ${ }^{1}$ \\ Prodi Diploma Kebidanan STIKES Bina Bangsa \\ Majene, Sulawesi Barat
}

Dikirim: 05/02/2021

Direvisi: 20/02/2021

Disetujui: 28/02/2021

\begin{abstract}
ABSTRAK
ASI Eksklusif adalah pemberian makanan hanya ASI saja tanpa tambahan makanan dan minuman apapun selama 6 bulan pertama kehidupan. Tujuan umum dari penelitian ini yaitu untuk memperoleh informasi secara kualitatif tentang penyebab rendahnya ASI Eksklusif di desa bonde wilayah kerja puskesmas campalagian kecamatan campalagian kabupaten polewali mandar tahun 2018.
\end{abstract}

Jenis penelitian ini yang dilakukan adalah penelitian kualitatif dengan pendekatan fenomologi untuk mengeksplorasi fenomena pemberian ASI Eksklusif di desa bonde. Penelitian ini menggunakan metode snowball sampling dengan 6 responden yang mempunyai bayi usia 0-24 bulan, tidak memberikan ASI Eksklusif yang bersedia diwawancara. dan yang menjadi informan kunci adalah petugas gizi puskesmas campalagian.

Teknik yang digunakan adalah triangulasi teknik dengan menggabungkan tiga cara observasi, wawancara mendalam, dan dokumentasi. Data hasil penelitian ini diolah secara manual dengan mengelompokan hasil wawancara sesuai tujuan penelitian dan selanjutnya dilakukanan alisisis (content analisys). Penelitian ini dilakukan 14 hari,yaitu sejak 17 juli sampai dengan 30 juli tahun 2018 di desa bonde kecamatan campalagian kabupaten polewali mandar provinsi Sulawesi barat.

Hasil penelitian ini menunjukan bahwa rendahnya pemberian ASI Eksklusif yang di sebabkan oleh factor pendorong dan kesimpulannya bahwa Faktor predisposisi (predisposisi factors) pemberian ASI Eksklusif pada bayi usia 0-24 bulan daerah pesisir adalah pengeahuan yang kurang dikalangan 
masyarakat, serta sikap dan kebiasaan negatif yang masih dianut terhadap pemberian ASI secara Eksklusif serta saran yang diberikan tidak mempercayai mitosmitos negatif yang merupakan salah satu kendala bagi ibu untuk menyusu, dan petugas kesehatan memaksimalkan upaya untuk meningkatkan informasi peberian asi serta membentuk kelas khusus tentang sikap pembeian asi eksklusif.

\section{PENDAHULUAN}

Upaya meningkatkan kualitas SDM, dimulai sejak janin dalam kandungan, masa bayi, balita, anak-anak sampai dewasa. Pemberian ASI Eksklusif pada bayi merupakan cara terbaik bagi peningkatan kualitas SDM sejak dini karena anak yang mendapat ASI akan tumbuh kembang secara optimal dengan demikian kualitas generasi penerus terjamin. ASI eksklusif adalah pemberikan hanya ASI saja tanpa memberikan makanan dan minuman lain kepada bayi sejak lahir sampai berumur 6 bulan, kecuali obat dan vitamin. Namun bukan berarti setelah pemberian ASI eksklusif pemberian ASI dihentikan, akan tetapi tetap diberikan kepada bayi sampai bayi berusia 2 tahun dengan makanan pendamping ASI(Kriselly, 2015)

Pemberian ASI menurunkan risiko kematian bayi akibat diare dan infeksi, sumber energi dan nutrisi bagi anak usia 6 sampai 23 bulan, serta mengurangi angka kematian di kalangan anakanak yang kekurangan gizi. ASI memiliki banyak manfaat bagi ibu dan bayi. Beberapa manfaat ASI bagi bayi yaitu sebagai perlindungan terhadap infeksi gastrointestinal, Sedangkan manfaat pemberian ASI bagi ibu yaitu mengurangi risiko kanker ovarium dan payudara, membantu kelancaran produksi ASI, sebagai metode alami pencegahan kehamilan dalam enam bulan pertama setelah kelahiran, dan membantu mengurangi berat badan lebih dengan cepat setelah kehamilan (WHO,distasi oleh Rumiasari 2012)
WHO memperkirakan pemberian asi ekslusif sampai usia 6 bulan mencegah kematian pada bayi dan anak-anak. Bayi dan anak-anak yang mendapatASI Eksklusif 14 kali lebih mungkin dapat bertahan hidup dibandingkan anak yang tidak menadapatkan asi. Mulai menyusui pada hari pertama setelah lahir dapat mengurangi resiko bayi baru lahir $45 \%$ namun hanya $39 \%$ bayi dibawah enam bulan diseluruh dunia mendpatkan ASI Ekslusi (Rilamasar, 2014) Menurut KemenKes RI 2016 bahwa persentase pemberian ASI Ekslusif pada bayi 0-6 bulan di Indonesia sebesar 54\%, namun angka tersebut masih jauh dari target nasional yang diharapkan dalam mencapai ASI Ekslusif seharusnya mencapai 80\% (Okratia, 2010)

Menurut UUD No.36/2009 pasal 129 ayat (1) Pemerintah bertanggung jawab menetapkan kebijakan dalam rangka menjamin hak bayi untuk mendapatkan Air Susu Ibu secara Eksklusif.

KEPMENKESNo.450/MENKES/SK/VI/2004

Tentang ASI Eksklusif menetapkan ASI eksklusif di Indonesia selama 6 bulan dan dianjurkan dilanjutkan sampai dengan anak berusia 2 tahun atau lebih dengan pemberian makanan tambahan yang sesuai (Wijayanti,2010).

Berdasarkan data Dinas Kesehatan Polewali Mandar Provinsi Sulawesi Barat tahun 2016 jumlah seluruh bayi di Polewali Mandar sebanyak 9.184 bayi namun yang mendapatkan ASI Eksklusif sebanyak 2390 bayi atau 26,0\% . Jumlah bayi di Kecamatan Campalagian sebesar 880 bayi namun yang mendapatkan ASI Eksklusif 58 bayi atau $6,6 \%$ dari data diatas jauh dari capaian target pemerintah sebesar 80\% ( Dinkes Kab. Polman2016 )

Beberapa hasil penelitian menunjukan terdapat beberapa hal yang mempengaruhi pemberian ASI Eksklusif penelitian di Depok menyatakan bahwa sebagian besar ibu sudah memiliki pengetahuan tentang ASI menyusui yang relatif baik. Namun pengetahuan ibu mengenaiASI Eksklusif relatif rendah. Begitu juga perilaku pemberian asi secara eksklusif pada umumnya mereka tidak dapat 
memberikan ASI secara eksklusif (Media,2011). Berdasarkan penelitian yang dilakukan Ridwan Amiruddin dan Rostia 2014 menunjukan bahwa ibu yang baru melahirkan lebih percaya kepada kebiasaan - kebiasaan keluarga, orang tuanya yang di lakukan secara turun temurun dari pada mengaplikasikan informasi dari petugas kesehatan. Sehingga kurangnya dari dukungan keluarga terutama dukungan dari ayah bayi dan orang tua mengakibatkan bayi tidak mendapat ASI Eksklusif.

\section{METODE PENELITIAN}

Desa Bonde terletak Di Kecamatan Campalagian Kabupaten Polewali Mandar yaitu sekitar $14 \mathrm{~km}$ dari kota Kabupaten Polewali Mandar, dimana luas wilayah 2.920,5 Ha.Jenis penelitian ini menggunakan metode penekitian kualitatif dengan pendekatan fenomologi yang bermaksud untuk mengetahui fenomena apa yang terjadi pada subyek peneliti tentang pemberian ASI Ekslusif di daerah pesisir.

\section{Populasi dan Sampel}

Jumlah responden yang menjadi subyek penelitian ini adalah ibu yang mempunyai bayi 6- 24 bulan sebanyak 5 responden dengan menggunakan metode purposive sampling dengaa kriteria yang telah di tentukan oleh peneliti yaitu, Ibu yang mempunyai bayi berumur 6-24 bulan, Ibu yang tidak memberikan ASI ekslusif pada bayinya, Berada di desa bonde, Bersedia menjadi responden

\section{Pengumpulan Data}

Tehnik pengumpulan data yang dilakukan dengan menggunakan metode triagulasi teknik yaitu pengumpulan data dengan bermacam-macam cara pada sumber yang sama.dalam metode ini dilakukan dengan menggabungkan tiga cara yaitu Observasi partisipatif, wawancara mendalam, dan dokumentasi.

\section{Analisis Data}

Data yang diperoleh dari lapangan jumlahnya cukup banyak sehungga perlu dicatatsecara teliti dan rinci. Seperti telah dikemukakan sebelumnya, semakin lama penelitian ke lapangan, maka jumlah data yang diperoleh akan semakin banyak, kompleks dan rumit untuk itu perlu segera di lakukan analisis data melalui reduksi data.

\section{HASIL DAN PEMBAHASAN}

Penelitian ini ingin mengetahui bagaimana fenomena pemberian ASI Eksklusif pada bayi usia - 24 bulan di desa bonde. Persentase pemberian ASI Eksklusif pada bayi masih tergolong rendah. Semua informan pernah memberikan ASI kepada bayinya namun bukan secara eksklusif dengan keadaan tertentu, bahkan ada ibu yang langsung memberikan susu formula pada awal kelahiran, pemberian makanan yang lain juga pernah diberikan kepada anaknya di usia lebih dini.

Pada penelitian ini semua informan yang diambil adalah ibu yang memiliki bayi berusia 6-24 bulan yang tidak mendapatkan ASI Eksklusif dan bersedia untuk diwawancarai.

Berdasarkan penelitian yang telah dilakukan dapat diindentifikasi fenomena pemberian ASI Eksklusif di daerah pesisir pada bayi 6-24 bulan yaitu faktor predisposisi (factor predisposisi), faktor pendukung (enabling factor), faktor pendorong (reinforcing factor)

Berdasarkan hasil yang telah dilakukan, faktor predisposisi yang menyebabkan terjadi fenomena pemberian ASI Eksklusif di daerah pesisir pada bayi 6-24 bulan di desa bonde adalah pengetahuan dan sikap yang kurang di masyarakat.. ASI merupakan makanan alamiah yang pertama dan utama bagi bayi baru lahir. ASI dapat memenuhi kebutuhan bayi akan energi dan gizi sampai umur tiga tahun pertama sehingga dapat mencapai tumbuh kembang yang optimal. Sejak kehamilan enam bulan, sel-sel itu saling berhubungan membentuk berbagai rangkaian fungional (sirkuit) yang kompleks, ibarat 
rangkaian microchip komputer. Proses itu berlangsung sangat cepat dan kompleks sampai umur tiga tahun, melambat di usia sekolah dan remaja. Kualitas kecerdasan anak tergantung pada kualitas sirkuit juga dipengaruhi oleh kualitas rangsangan (stimulasi) yang didapat sejak dikandungan sampai umur tiga tahun pertama. Karena tumbuh kembang otak sangat cepat maka sampai berumur satu tahun, $60 \%$ energi dari makanan bayi digunakan bagi pertumbuhan otak.

Kandungan ASI begitu luar biasa. Maka tidak salah jika ASI dianggap sebagai air ajaib anugrah ilahi rabbi. Karena sudah menjadi karunia tuhan maka ASI adalah asupan gizi yang luar biasa bagi bayi. Namun, masih banyak ibu yang kurang yakin akan keunggulan ASI dibandingkan dengan susu formula. Mungkindia yakin, tapi dia tidak yakin pada kandungan ASI dimilikinya. Setiap tahunnya ditemukan penelitian baru mengenai keunggulan ASI (the baby book)

\section{KESIMPULAN}

Faktor predisposisi (predisposisi factors) pemberian ASI Eksklusif pada bayi usia 024 bulan daerah pesisir adalah pengeahuan yang kurang dikalangan masyarakat, serta sikap dan kebiasaan negatif yang masih dianut terhadap pemberian ASI secara Eksklusif.. Faktor pendorong (enabling factors) pemberian ASI Eksklusif pada bayi usia 0-24 bulan adalah keadaan tertentu seperti pekerjaan ibu yang tidak memiliki waktu untuk menyusu bayinya sampai usia 6 bulan, serta pemberian MP-ASI yang sangat cepat diberikan dibawah usia 0-6 bulan. Faktor pendoorong (reinforcing factors) pemberian ASI Eksklusif pada bayi usia 0- 24 bulan adalah kurangnya peran keluarga seperti orang tua, mertua, suami dang anggota keluarga lain, serta dukungan petugas kesehatan yang kurang dan informasi mengenai ASI Eksklusif yang kurang.

\section{DAFTAR PUSTAKA}

A, Wahab. 2013. Pengantar Statistik Untuk Pendidikan dan Sain. Edisi Pertama. Yogyakarta: KutubWacana.

A, Wahab 2012. Pengantar Riset( Bidan Kesehatan, Kebidanan, Dan Keperawatan). Edisi Pertama. Yogyakarta: KutubWacana.

Arisama. 2010. Gizi Dalam Daur Hidup. Jakarta: EGC.

Anonim, Cuti Melahahirkan Dan Memberikan ASI Eksklusif in www.kompas.com 2011, diakses 21 juni 2018

Citerawati,Y, W. 2016. Makanan Pendamping Asi. Edisi Pertama. Yogyakarta. Trans Medika.

Dinkes RI, 2016. Profil Kesehatan Kabupaten Polewali Mandar http://www.dinkes.com Di Aksespada 02 Januari 2018 pada 14:30

Eni, Atikah. 2010. Kapita Selekta Asi dan Menyusui. Cetakan Pertama. Yogyakarta. Nuha Medika.

Haryono,Setianingsih. 2014. Manfaat ASI EklusifUntukBuahHati Anda.

PustakaBaru,Wonosari, Sendagadi.

Kriselly, yurina. 2012 Studi Kualitatif Terhadap Rendahnya Pemberian Asi Eklusif Di Wilayah Kerja Puskesmas Kerang Pangi Kecamatan Katingan Hilir Kabupaten Katingan Profinsi Kalimanta Tengah.

Nugroho, T. 2011. Asi dan Tumor Payudara. Cetakan Pertama. Yogyakarta. Nuha Medika

Nirwana, B , A. 2014. Asi dan Susu Formula Kandungan dan Manfaat Asi dan Susu Formula. Cetakan Pertama. Yogyakarta. Nuha Medika.

Oktaria . 2012 Hubungan Pengetahuan Ibu Tentang Asi Eksklusif, Menyusui Dini Tempat 
Terhadap Pemberian Makanan Praeakteal Pada Bayo 0-5 Bulan Di wilayah Puskesmas Balai Agung Kota Sekayu Kabupaten Musi Banyumasin Depok Fakulatas Kesehatan Masyarakat Peminatan Kebidanan Komunitas Universitas Indonesia.

Rumiasari. 2012 Penelitian Kualitatif Gambaran Pemberian Asi Eksklusif di Puskesmas Jati Rahayu. Bekasi Fakultas Ilmu Keperawatan.

RW, Hapsari. 2014 Mengenal Asi Ekslusif. Jakarta :Rineka Cipta.

Sugiyono. 2012. Metode penelitian kombinasi (mixed methods). Bandung: alfabetan.

Samad,Abdul. 2008. Determinan Pemberian Asi Ekslusif Pada Bayi 0-6 Bulan Di Desa Pessui Kecamatan Luyo Kabupaten Polewai Mandar: Sekolah Tinggi Ilmu Kesehatan Bina Bangsa Majene.

Tim Revisi, 2016. Buku Panduan Skripsi S1 Kesehatan Masyarakat. LembagaPeneltian dan Pengabdian Masyarakat Sekolah Tinggi Ilmu Bina Bangsa Majene.

Wijayanti, Winda. 2010. Hubungan Antara Pemberian Asi Ekslusif Terhadap Kejadian Diare Pada Bayi Umur 0-6 Bulan Di Puskesmas Gilingan Kecamatan Banjarmasin Surakarta. Surakarta Fakultas Kedokteran Universitas Sebelas Maret.

Yuli Astutik Reni, 2014. Payudara Dan Laktasi. Jakarta: salemba medika 